\title{
REPOSISI PERAN ULAMA DALAM PENERAPAN SYARIAT ISLAM DIACEH
}

\author{
Repositioning of Ulama Role in The Application Islamic Law in Aceh \\ Oleh: Abidin Nurdin* \\ *Dosen Fisipol Universitas Malikussaleh Banda Aceh \\ Alamat Kantor: Bukit Indah Kota Lhokseumawe, Prov. Daerah Istimewa Aceh \\ Email: abidin maiene@vahoo.co.id
}

\begin{abstract}
Abstrak
Penelitian inimembahasperanMPUdalam penerapan Syariat Islam Aceh. Masalah utamayangdikajiadalahperan ulama dalam masyarakat Aceh, posisi dan peran MPU serta faktor-faktor yang mempengaruhinya dalam pelaksanaan Syariat Islam diAceh. Kemudian studi tersebut merupakan penelitian kualitatifyakniprosedur penelitian yang menghasilkan data deskriptif berupa kata-kata yang tertulis atau lisan dari orang-orang atau lembaga dan prilaku yang dapat diamati. Sedangkan dilihat dari obyeknya maka penelitian ini adalah studi lapangan (Field research,) yaitu riset yang dilakukan dengan menjadikan MPU di Provinsi Aceh sebagai obyek kajian. Dari penelitian ditemukan bahwa ulama merupakan kelompok elityang ada dalam masyarakat yang mempunyai pengaruh yang kuat sepanjang sejarah Aceh sampai saat ini. MPU memainkan peran yang cukup signifikan terutama dalam proses legislasi qanun, mem berikan fatwa dan masukan kepada lembaga eksekutif, legislatif dan seluruh stakeholder di Aceh tentang kebijakan daerah, terutama yang terkait dengan syariat Islam. Karena itu, MPU telah melakukan reposisiyang mempunyai nilai tawar dan pengaruh yang lebih kuat dibanding sebelumnya. Kemudian, faktoryang memengaruhi peran MPU yaitu, keseriusan pemerintah yang masih rendah, SDMMPU sudah memadai mesMpun masih perlu ditingkatkan dan legitimasi masyarakat yang cukup tinggi.
\end{abstract}

Kata Kunci: Peran, MPU, Syariat Islam dan Aceh

Abstract

This study discusses the role ofthe MPU in the application of Islamic law in Aceh. The mainproblem studied is the role of ulama in Aceh, the position and role of MPU and the factors that influence the implementation of Islamic law in Aceh. Then the study is a qualitative research study that is the procedure that produces descriptive data in the form of words written or spoken ofpersons or institutions and behavior can be observed While the views ofthe object of this research is afield study (field research) is to research carried out by making the MPU in the province ofAceh as an object of study. From the study it was found that Ulama is a group of elite scholars that exist in communities that have a strong influence in the history of Aceh to date. MPUplays a significant role particularly in the legislative process qanum, giving fatwa and advise the executive, legislative and all stakeholders in Aceh on regional policy, especially related to the Islamic law. Therefore, the MPU has repositioned the value offresh and have a stronger influence than everbefore. Then, the factors that influence the role of the MPU, the seriousness of the government is stilllow, theMPU has adequate human resources although it still needs to be improved and the public legitimacy fairly high.

Keywords: role, MPU, and the Islamic law inAceh

\section{PENDAHULUAN}

$\mathrm{M}$ ajelis Permusyawaratan Ulama (MPU) merupakan salah satu lembaga yang terbentuk pasca pemberlakuan otonomi khusus yang kemudian diikuti penerapan Syariat Islam di Aceh. MPU adalah lembaga ulama yang memiliki pengaruh dan legitimasi dalam masyarakat dan pemerintahan sejak masa lalu sampai penerapan Syariat Islam pada 1 Muharram $1423 \mathrm{H}$, yakni pada masa Gubernur Abdullah Puteh.

Penerapan Syariat Islam di Aceh paling tidak mempunyai tiga legitimasi, yaitu: historis, kultural, dan yuridis. Legitimasi historis dapat dilihat dari sejarah masa lalu ketika Islam pertama kali masuk ke Aceh dan menjadi anutan masyarakat hingga berdirinya beberapa kerajaan Islam, yaitu Peureulak, Samudera Pasai, dan Aceh Darussalam. Bahkan pasca kemerdekaan Tgk. M. Daud Beureueh pada 17 Juni 1948 pernah meminta untuk memberlakukan Syariat Islam kepada Presiden Soekarno ketika datang ke Aceh, tetapi permintaan ini tidak dikabulkan. Padahal kunjungan Soekarno juga berhasil mengumpulkan 50 $\mathrm{kg}$ emas untuk membeli pesawat Seulawah dan Da-

Penjelasan mengenai masalah latar belakang penerapan syariat Islam di Aceh dapat dibaca dalam Al Yasa' Abubakar 2005. Syari'at Islam di Provinsi Aceh Paradigma Kebijakan dan Kegiatan. (Banda Aceh: Dinas Syari'at Islam Provinsi Nanggroe Aceh Darussalam, h. 26 dan 390. Rifyal Ka'bah 2004. Penegakan Syari'at Islam di Indonesia, Jakarta: Khairul Bayan, h. 26. Lihat juga Taufik Adnan Amal dan Syamsu Rizal Panggabean, Politik Syariat Islam: Dari Indonesia Hingga Nigeria, Jakarta: Pustaka Alvabet, h. 12-54. 
kota, kapal terbang pertama Indonesia sebagai sumbangan rakyat Aceh. ${ }^{2}$

Legitimasi kultural yakni secara adat dan budaya masyarakat Aceh mencerminkan nilai-nilai yang islami. Misalnya struktur pemerintahan paling bawah yang dikenal dengan istilah gampong (desa), dipimpin oleh seorang kepala desa yang disebut keuchik, ia mengurusi masalah administrasi dan pemerintahan, sedan gkan yang mengurusi masalah agama adalah teungku imum. Struktur ini teraplikasi sama sampai pada level paling atas, yaitu negara (kerajaan), ada sultan dan qadhi malikul adil (ulama). Sehingga dalam pepatah Aceh disebut "Adat bak potuemeurehum hukom bak syiah kuala." (adat berasal dari pemerintah, dan hukum berasal dari ulama).

Sedangkan legitimasi yuridis yakni ditetapkannya UU No. 44 Tahun 1999 tentang penyelenggaraan keistimewaan Provinsi Daerah Istimewa Aceh, dan UU No. 18 tahun 2001 serta yang kemudian diperkuat oleh UU No. 11 tahun 2006 tentang Pemerintahan Aceh terutama pada Pasal 138-140. Pasal 9 UU No. 44 tahun 1999 disebutkan:

(1) daerah membentuk sebuah badan yang anggota terdiri atas para ulama; (2) badan sebagaimana dimaksud pada ay at (1) bersifat independen yang berfungsi memberikan pertimbangan terhadap kebijakan daerah, termasuk bidang pemerintahan, pembangunan dan kemasyarakatan serta tatanan ekonomi Islami.

Pelaksanaan syariat Islam tersebut membawa babak baru dalam proses pemerintahan di Aceh. Karena dibutuhkan banyak perangkat baru misalnya, bagaimana syariat itu diberlakukan, lembaga apa yang menjalankan, siapa yang mengawasi, mazhab fiqih apa yang diterapkan, masalah apa dan pertama yang harus diatur oleh pemerintah, dan seterusnya. Untuk menjawab pertanyaan itu, pemerintah telah membentuk Dinas Syariat Islam pada tahun 2001 sebagai lembaga yang bertanggung jawab dalam pelaksanaan syariat Islam, kemudian mengubah Majelis Ulama Indonesia (MUI) menjadi MPU sebagai mitra legislatif dan eksekutif dalam memberikan masukan dan pertimbangan tentang kebijakan daerah terutama masalah pelaksanaan syariat Islam.

Untuk menjawab sejumlah pertanyaan tersebut, maka kehadiran lembaga ulama dalam hal ini MPU sangat signifikan. Sebab selama ini Dewan Perwakilan Rakyat Aceh (DPRA) yangmempunyai fungsi legislasi akan menemui kendala, sebab tidak semua anggota legislatif memiliki kemampuan untuk memahami syariat Islam secara baik. Sedangkan untuk membuat qanun (di Provinsi lain disebut perda) seseorang harus mempunyai kemampuan tentang ilmu-ilmu keislaman. Bagaimana mungkin seorang anggota legislatif menuangkan isi Alquran dan Sunnah dalam bentuk qanun jika mereka tidak mempunyai pengetahuan tentang hal tersebut, boleh jadi ada beberapa anggota DPRA yang memiliki latar pendidikan seperti IAIN atau dayah (pesantren), tetapi jumlahnya sedikit.

Oleh karena itu, disinilah letak peran penting MPU sebagai lembaga yang mempunyai fungsi sebagai mitra legislatif dan eksekutif untuk melakukan legislasi qanun syariat Islam dan memberikan pertimbangan kepada seluruh stakeholder di Aceh terkait dengan pelaksanaan syariat Islam. Daniel Djuned menilai yang memahami substansi syariat jelas adalah ulama, karena itu dalam proses legislasi qanun ulama harus diberikan ruang dan wewenang yang lebih dengan tetap melakukan sinergitas dengan lembaga lain. ${ }^{4}$ Bahkan menurut Muslim Ibrahim, Ketua MPU Provinsi Aceh bahwa MPU bersifat legislatif independen, ${ }^{5}$ artinya dapat terlibat dalam proses legislasi qanun tetapi tetap independen. Maksudnya, karena ia dapat dianggap tidak dipengaruhi oleh kepentingan politik jika dibandingkan dengan anggota legislatif dan eksekutif.

Karena itu, kajian ini cukup menarik untuk dilakukan mengingat peran MPU dalam proses tersebut cukup sentral, disinilah letak urgensi stuck" tersebut karena lembaga ulama bukanlah unsur baru yang muncul dalam dinamika masyarakat dan pemerintahan Aceh, namun demikian lembaga tersebut telah lama ada, tetapi peran dan posisinya yang

\footnotetext{
- Al Yasa' Abubakar, Pelaksanaan Syariat Islam di Aceh: Sejarah dan Prospeknya dalam Fairus M. Nur Ibr 2004. Syari 'at di Wilayah Syariat: Pernik-Pernik Islam di Nanggroe Aceh Darussalam, Banda Aceh: Dinas Syari'at Islam, h. 27.

${ }^{3}$ Muhammad Zainuddin 1961. Tarich Atjeh dan Nusantara, Medan: Iskandannuda, h. 313.

‘Daniel Djuned, Syariat Bagaimana Yang Mesti Diaplikasikan, dalam Fairus M. Nur Ibr 2002. Syari'at di Wilayah Syariat: Pemik-Pemik Islam di Nanggroe Aceh Darussalam, Banda Aceh: Dinas Syari'at Islam, h. 74.

${ }^{5}$ Istilah legislatif independen diungkapkan oleh Muslim Ibrahim, Ketua MPU lebih lanjut lihat Muslim Ibrahim 2002. Rekonstruksi Peran Ulama di Masa Depan, dalam Fairus M. Nur Ibr, Syari'at di Wilayah Syariat: Pernik-Pernik Islam di Nanggroe Aceh Darussalam, Banda Aceh: Dinas Syari'at Islam,h. 245-252.
} 
berbeda, seiring dengan perubahan dan transformasi sosial politik yang terjadi di Aceh. Berangkat dari latar belakang tersebut dapat dirumuskan beberapa masalah penelitian, yaitu: 1). Bagaimana peran ulama dalam masyarakat Aceh? 2). Bagaimana posisi peran MPU dalam pelaksanaan Syariat Islam di Aceh? Serta 3). Faktor-faktor apa yang memengaruhi posisi MPU dalam pelaksanaan Syariat Islam di Aceh?

Terkait dengan pembahasan tersebut ada beberapa buku dan tulisan yang dianggap sebagai kajian awal, yaitu: Ma'mun Mu'min menilai bahwa ulama di Aceh cukup berperan dakwah dan politik terutama sebagai mediator antara masyarakat dan pemerintah. Meskipun penelitian ini lebih terfokus pada ulama yang berada dalam partai politik yang disebutnya sebagai ulama kekaryaan. Kemudian, Sri Suyantamenjelaskan bahwa ulama di era reformasi cukup berperan termasuk proses perdamaian MoU Helsinki dan ikut terlibat dalam legislasi qanun. Menurutnya, MPU telah berperan dengan lahirnya Undang-Undang Keistimewaan Aceh dan beberapa qanun lainnya. Namun demikian, kedua kajian ini dilakukan sebelum pemberlakukan UUPA2006 yang secara sosia! politik telah banyak berubah.

Daniel Djuned mengatakan bahwa MPU sebagai lembaga ulama yang lebih berada digarda depan dalam perumusan qanun harus diberikan ruang yang jelas agar peran dan kerjanya tidak tumpan tindih dengan lembaga lainnya. ${ }^{8}$ Selain itu, Muslim Ibrahim menilai bahwa MPU merupakan lembaga legislatif independen, artinya bahwa ulama merupakan mitra sejajar pemerintah yang memiliki peran tidak hanya dalam proses legislasi, tetapi juga sosialisasi qanun.' Kedua kajian ini cukup berkaitan dengan penelitian yang akan penulisan tersebut, meskipun belum dijelaskan peran MPU pasca pemberlakuan Syariat Islam di Aceh sebagaimana yang akan diteliti dalam penelitian tersebut.

Selain dari tulisan tersebut, M. Samir Fuady mengemukakan bahwa MPU berperan dalam proses penerapan syari'at Islam terutama dalam proses legislasi qanun dan pengawasan pelaksanaan syari'at Islam. ${ }^{10}$ Namun sayangnya kajian ini lebih bersifat deskriptif, tanpa dukungan data yang bersifat ekploratif seperti wawancara tentang bagaimana prakteknya di lapangan.

Berangkat dari beberapa kajian yang telah disebutkan di atas dianggap belum secara khusus membahas hal tersebut, meskipun Samir Fuady telah melakukan analisis yang relatif masih lebih berkembang dibandingkan dengan penulis lainnya, namun demikian tinjauan pustaka ini dapat menjadi kajian atau bahan awal dari penelitian ini. Kajian awal ini yang kemudian dianalisis lebih jauh pada saat penelitian.

\section{Metode Penelitian}

Studi ini merupakan penelitian kualitatif yakni prosedur penelitian yang menghasilkan data deskriptif berupa kata-kata yang tertulis atau lisan dari orangorang atau lembaga dan prilaku yang dapat diamati." Sedangkan dilihat dari obyeknya maka penelitian ini adalah studi lapangan (field research) yaitu riset yang dilakukan yang menjadikan peran MPU di Provinsi Aceh sebagai obyek kajian. Kemudian teknik pengumpulan data yang dipakai adalah wawancara yaitu dengan mengajukan pertanyaan-pertanyaan kepada responden yang merupakan informan kunci. Selanjutnya studi dokumentasi, yakni menelaah rujukan berupa buku, artikel, makalah dan sejumlah literatur terkait dengan peran MPU dalam pelaksanaan syariat Islam di Aceh.

\section{PEMBAHASAN}

\section{Dinamika Peran Ulama di Aceh}

Peran dan pengaruh ulama sejak lama telah dilakukan sejak Islam masuk ke Aceh pertama kali di Nusantara dan Asia Tenggara. Peran ulama sebagai mufti sultan, fatwa yang dikeluarkan oleh ulama cukup berpengaruh dalam pengambilan kebijakan dan arah

\footnotetext{
'Ma'mun Mu'min 1998. Peran Dakwah dan Politik Ulama Kekaryaan di Daerah Istimewa Aceh, Banda Aceh: Program Pascasarjana IAIN Ar-Raniry.

'Sri Suyanta 2006. Hubungan Ulama dan Umara: Peran Ulama Aceh di Reformasi, Jakarta: Pascasarjana UIN Jakarta.

${ }^{s}$ Daniel Djuned. Syariat Bagaimana..., h. 74.

'Muslim Ibrahim. Rekonstruksi Peran Ulama..., h. 245-252.

${ }^{10}$ M. Syamir Fuady 2007. Legislasi Hukum Islam di Era Modern: Tinjauan tentang Peran MPU dalam Pembuatan Qanun Syari'at Islam di Provinsi Nanggroe Aceh Darussalam, Banda Aceh: Pascasarjana IAIN Ar-Raniry.

"Lexi J. Moleong 1997. Metodologi Penelitian Kualitatif, Bandung: Rosda Karya, h. 3.

${ }^{12}$ Yusny Saby, 1995. Islam and Social Change: Tlie Role The Ulama In Achenese Society, Temple University: Dissertation.

"Azyumardi Azra 1998. Jaringan Ulama: Timur-Tengah dan Kepulauan Nusantara AbadXVII dan XVIIIMelacak Akar-Akar Pembaharuan Pemikiran Islam di Indonesia, Edisi Revisi, Jakarta: Kencana, h. 202.
} 
dipisahkan dengan syariat. Syariat menjadi urat nadi masyarakat Aceh, tidak dapat terbantahkan, maka ulama adalah orang yang mengerti, memahami dan mengalamalkan syariat. $^{18}$

Tugas dan fungsi MPU sebagaimana disebutkan dalam Peraturan Daerah Pasal (4) No. 3 Tahun 2000 mempunyai tugas memberi masukan, pertimbangan, bimbingan dan nasehat serta saran-saran dalam menentukan kebijakan daerah dari aspek Syariat Islam, baik kepada Pemerintah Daerah maupun kepada masyarakat di daerah. Kemudian direvisi dengan Qanun No. 2 tahun 2009, pasal (4) MPU dan MPU kabupaten/kota berfungsi: a). Memberikan pertimbangan terhadap kebijakan daerah, meliputi bidang pemerintahan, pembangunan, ekonomi, sosial budaya dan kemasyarakatan; b). Memberikan nasehat dan bimbingan kepada masyarakat berdasarkan ajaran Islam. ${ }^{19}$ Kemudian mengenai tugas MPU yaitu: a). Memberikan masukan, pertimbangan dan saran kepada Pemerintah Aceh dan DPRA dalam menetapkan kebijakan berdasarkan syariat Islam; b). Melakukan pengawasan terhadap penyelenggaraan pemerintahan, kebijakan daerah berdasarkan syariat Islam; c) Melakukan penelitian, pengembangan, penerjemahan, penerbitan, dan pendokumentasian terhadap naskah-naskah yang berkenaan dengan syariat Islam; d) melakukan pengkaderan ulama. ${ }^{20}$

MPU berasal dari dua elemen, yaitu ulama dan cendikiawan muslim. Ulama adalah tokoh panutan masyarakat yang memahami secara mendalam ajaran Islam dari Alquran dan Hadis serta mengamalkannya. Sedangkan cendikiawan Muslim adalah ilmuwan yang mempunyai integritas moral dan memiliki keahlian tertentu secara mendalam serta mengamalkan ajaran Islam. ${ }^{21}$ Sebagaimana dikemukakan oleh Nurjannah Ismail, salah seorang anggota MPU;

Lembaga MPU merupakan representasi dari ulama dayah (pesantren salafiyah) dan ulama yang berasal dari kampus atau intelektual tidak ada perbedaan yang menonjol antara kedua kelompok tersebut. Karena ada beberapa ulama kampus yang mempunyai latar belakang dayah yang kuat. ${ }^{22}$

Berdasarkan Qanun No. 2 Tahun 2009, secara struktur keorganisasian MPU terdiri dari: 1) Majelis syuyukh yang terdiri dari 9 orang yang dipilih dari ulama kharismatik yang bukan anggota MPU; 2) Pimpinan yang terdiri dari satu ketua dan tiga wakil ketua yang dipilih dalam rapat paripurna khusus; 3) Komisi yaitu komisi A bidang fatwa, kajian qanun dan perundangundangan, komisi B bidang pendidikan, penelitian dan pengembangan serta ekonomi umat, komisi $\mathrm{C}$ bidang dakwah, pemberdayaan keluarga dan generasi muda; 4) Panitia musyawarah; 5) Badan otonom dan 6) Panitia khusus. ${ }^{23}$

\section{Reposisi MPU dalam Penerapan Syariat Islam}

Jika dibandingkan secara sekilas antara MPU dan MUI, maka tampak hampir sama tetapi sesungguhnya kedua lembaga tersebut memiliki legitimasi dan kewenangan yang berbeda. Saat masih bernama MUI, ulama Aceh melalui lembaga tersebut bertugas memberikan nasihat kepada Pemerintah Daerah Aceh. Nasihat tersebut bisa dipatuhi, tetapi seringkali nasehat itu tidak digubris. Ini karena lembaga tersebut tidak mempunyai dasar-dasar yuridis yang kuat dalam hierarki peraturan perundang-undangan. Dengan kedudukan ulama dalam wadah MPU sekarang ini, lembaga ulama ini mempunyai dasar hukum yang lebih jelas dalam UU dan qanun. Berbeda dari MUI, MPU lebih bersifat independen dan berfungsi memberikan pertimbangan terhadap berbagai kebijakan daerah, seperti bidang pemerintahan, pembangunan, sosial kemasyarakatan, serta termasuk pula tatanan ekonomi yang Islami. MPU dalam menyelenggarakan tugas mempunyai fungsi menetapkan fatwa hukum dan memberikan pertimbangan, baik diminta atau tidak, terhadap kebijakan pemerintahan daerah.

Ringkasnya, transformasi lembaga ulama menjadi MPU dapat dikatakan sebagai babak baru peran ulama

\footnotetext{
${ }^{18}$ Wawancara dengan Dr. Nurjannah Ismail, Anggota Devvan Pertimbanga Ulama MPU Provinsi Aceh, Kamis 7 Mei 2009 di Fakultas Adab IAIN Ar-Raniry, Banda Aceh.

${ }^{19}$ Perda Nomor 3 Tahun 2000 Tentang Pembentukan Organisasi Dan Tata Kerja Majelis Permusyawaratan Ulama (MPU) Provinsi Daerah Istimewa Aceh.

${ }^{20}$ Qanun Nomor 2 Tahun 2009 Tentang Majelis Permusyawaratan Ulama.

${ }^{21}$ Qanun No. 2 Tahun 2009 Tentang Majelis Permusyawaratan Ulama, terutama pada Pasal (1) point 11,12 dan 13.

${ }^{22}$ Wawancara dengan Dr. Nurjannah Ismail, Anggota Dewan Pertimbanga Ulama MPU Provinsi Aceh, Kamis 7 Mei 2009 di Fakultas Adab IAIN Ar-Raniry, Banda Aceh.

${ }^{23}$ Qanun No. 2 Tahun 2009 Tentang Majelis Permusyawaratan Ulama, terutama pada Pasal (7).
} 
di Aceh. Sebab, organisasi sebelumnya, yaitu MUI, tampak tidak independen bahkan boleh dikatakan subordinat dari pemerintah. Hadirnya MPU menandakan terjadinya reposisi kedudukan ulama, atau kembali ditempatkan pada posisi yang layak, setara dengan pemerintah dan DPRA. Dalam hal ini, MPU memperoleh fasilitas dan dana dari Anggaran Pendapatan dan Belanja Daerah (APBD) untuk melaksanakan program-programnya. Saat masih menjadi MUI, karena tidak punya alokasi dana khusus dari pemerintah, lembaga ulama Aceh ini seolah menjadi pengemis yang meminta-minta dana dari pemerintah atau pihak lainnya untuk melaksanakan program sebagaimana MUI pusat dan provinsi lainnya di Indonesia.

Pada konteks ini MPU merupakan pihak yang dianggap penting untuk ikut menentukan kebijakan pemerintahan Aceh terutama yang berkaitan dengan syari'at Islam. Jika dibandingkan, walaupun sama-sama merupakan lembaga ulama, posisi MPU jelas berbeda dengan MUI yang berada pada tingkat nasional maupun pada tingkat provinsi lainnya. Peran MPU dalam penerapan syariat Islam dapat dikategorikan dalam dua hal yaitu; legislasi qanun dan memberikan masukan dan pertimbangan kepada stakeholder baik berupa fatwa maupun tausyiah yang terkait dengan syariat Islam maupun bukan.

\section{a. Legislasi Qanun}

MPU memiliki peran kunci dalam implementasi syari'at Islam di Aceh terutama dalam konteks negara bangsa. Peran kunci tersebut adalah keterlibatannya dalam proses legislasi qanun, baik pembuatan draft maupun pembahasan dengan pihak eksekutif dan legislatif. ${ }^{24}$

Namun demikian, proses legislasi qanun mengalami beberapa kendala karena lembaga seperti legislatif dan eksekutif mempunyai keterbatasan. Karena itu peran MPU cukup signifikan, untuk melakukan qanunisasi yang bersumber dari Alquran dan hadis, hal ini bukan perkara yang mudah. Diperlukan ilmu yang cukup mendalam tentang hukum Islam untuk menggali hukum dari sumbernya kemudian dibuat dalam bentuk qanun. Hal ini dijelaskan oleh Muslim Ibrahim.
Proses legislasi qanun syariat Islam selalu melibatkan MPU, bahkan lembaga ini merupakan dapur awal dari semua qanun tentang syariat Islam sebelum dibahas pada tingkat pemerintah melalui Biro Hukum juga Dinas Syariat Islam dan lembaga terkait lainnya (Mahkamah Syariyah). Sesudah dibahas pada tingkat ini, selanjutnya dibawa ke DPR untuk dibahas dalam komisi yang membidani syariat Islam. Setelah semua pihak setuju dengan qanun tersebut pada tahap akhir qanun tersebut disahkan oleh tiga lembaga yaitu; DPRA, Pemerintah dan MPU. Meskipun pada akhirnya qanun tersebut ditetapkan oleh Pemerintah dalam hal ini Gubernur sebagai kepala pemerintahan. Terkait dengan qanun yang bukan syariat Islam misalnya; qanun kesehatan, pariwisata, juga tentang aliran sesat serta qanun lainnya, MPU hanya memberikan saran. Maksudnya sebelum qanun tersebut disahkan, terlebih dahulu harus melalui meja MPU, pada konteks inilah MPU memberikan pertimbangan, saran dan tausiyah. ${ }^{26}$

Pandangan Muslim Ibrahim tersebut dipertegas oleh Burhanuddin (anggota DPRA) bahwa ada aturan yang sudah ditetapkan yakni semua qanun harus meminta pertimbangan MPU. Bukan hanya terkait dengan syariat Islam tetapi semua qanun yang akan ditetapkan oleh DPRA harus meminta pertimbangan dan masukan dari MPU;

Kontribusi MPU berada di garda depan dalam proses legislasi qanun syariat Islam selama ini. Setiap pembahasan di DPRA mengundang secara tetap dan mereka hadir memberi masukan, pandangan dan nasehat terhadap qanun yang akan disahkan oleh dewan bersama pemerintah. Karena dalam jalannya pemerintahan MPU adalah lembaga yang setara dengan DPRA. Kemudian pasca lahirnya Qanun No. 3 tahun 2007 tentang tata cara pembuatan qanun, maka salah satu pasalnya menyebutkan bahwa seluruh produk qanun dan perundang-undangan tidak boleh bertentangan dengan syariat Islam. Karena itu, disinilah peran sentral MPU dalam menjalankan fungsinya. Seharusnya semua qanun yang akan ditetapkan terlebih dahulu mendapat masukan dan pembahasan pada tingkat MPU. Apakah sejalan h. 156 .

${ }^{24}$ Arskal Salim 2008. Challenging The Seculer State: The lslamizalion of Law In Modem Indonesia. Honolulu: University of Hawaii Press,

${ }^{25}$ Daniel Djuned, Syariat Bagaimana..., h. 74.

${ }^{26}$ Wawancara dengan Prof. Dr. Muslim Ibrahim, Ketua MPU Provinsi Aceh dan Guru Besar IAIN Ar-Raniry, Rabu 29 April 2009 di Kantor MPU, Banda Aceh. 
dengan syariat atau tidak. Hal ini belum terealisasi dan teraplikasi secara baik. Seharusnya semua draft dan yang telah disahkan dievaluasi oleh MPU. ${ }^{27}$

Selanjutnya, sejak MPU berdiri dan mulai terlibat dalam proses legislasi yang melahirkan qanun syariat Islam yang telah disahkan oleh legislatif dan eksekutif antara lain:

1. Per da Nomor 5 Tahun 2000, Tentang Pelaksanaan Syariat Islam;

2. Perda Nomor 6 Tahun 2000, Tentang Penyelenggaraan Pendidikan;

3. Perda Nomor 7 Tahun 2000, Tentang Penyelenggaraan Kehidupan Adat;

4. Perda Nomor 33 Tahun 2001, Tentang Susunan Organisasi dan Tata Kerja Dinas Syariat Islam;

5. Qanun Nomor 10 Tahun 2002, Tentang Peradilan Syariat Islam;

6. Qanun Nomor 11 Tahun 2002, Tentang Pelaksanaan Syariat Islam Bidang Aqidah, Ibadah, dan Syiar Islam;

7. Qanun Nomor 9 Tahun 2003, Tentang Hubungan Tata Kerja MPU dengan Eksekutif, Legislatif, dan Instansi lainnya;

8. Qanun Nomor 12 Tahun 2003, Tentang Minuman Khamar dan Sejenisnya;

9. Qanun Nomor 13 Tahun 2003, Tentang Maisir (Perjudian);

10. Qanun Nomor 14 Tahun 2003, Tentang Khalwat (Mesum). ${ }^{28}$

\section{b. Pertimbangan Tentang Kebijakan Daerah}

Pertimbangan tentang kebijakan daerah yang dimaksud adalah hal-hal yang terkait dengan syariat Islam atau tidak terkait dengan syariat. MPU memiliki peran memberikan pertimbangan dalam bentuk fatwa, tausyiah atau rekomendasi. Bahkan tidak hanya terbatas pada pihak eksekutif dan legislatif saja, terkait dengan pembangunan di Aceh tetapi semua aspek dan kepada semua stakeholder di Aceh. Sebagaimana disebutkan oleh Nurjannah Ismail;
Terkait dengan proses legislasi qanun syariat Islam MPU berperan aktif misalnya dalam pembuatan qanun maisir, khalwat, dan khamar. MPU memberikan masukan kepada DPRA dan pemerintah dalam proses tersebut. Juga melibatkan lembaga lain misalnya MAA (Majelis Adat Aceh) dan MPD (Majelis Pendidikan Daerah). ${ }^{29}$

Oleh karena itu, peran MPU bukan hanya memberikan pertimbangan dalam hal-hal agama ansich, tetapi juga bidang pemerintahan, ekonomi, sosial budaya dan kemasyarakatan. Hal ini menunjukkan bahwa ada otoritas yang lebih luas yang diberikan oleh pemerintah sebagaimana harapan masyarakat terhadap MPU. Sebagai contoh fatwa dan tausyiah, sebagai berikut:

1. Fatwa No. 06 tahun 2003 Tentang syarat-syarat keramaian, di antara isi fatwa tersebut penonton harus dipisahkan antara laki-laki dan perempuan; harus memakai pakaian yang sopan dan menutup aurat;

2. Tausyiah No. 01 Tahun 2004 Tentang Pemilihan Umum, yang berisi bahwa semua umat Islam harus menggunakan hak pilihnya, setiap orang Islam wajib menyukseskan pemilihan umum, dalil yang digunakan bahwa memilih kepala negara untuk mengurus umat adalah wajib.

3. Fatwa No. 03 Tahun 2005 Tentang Perlindungan atas Tanah, Hak Nasab Bagi Anak Yatim, Hak Isteri dan Ahli Waris Nafqud Akibat Gempa dan Tsunami; antara lain berisi hukum memindahkan atau menyembunyikan nasab (asal-usul) seseorang adalah haram dan tidak sah; anak yatim yang tidak ada lagi wali nasab, atau was hi dapat ditetapkan pengasuhnya oleh Mahkamah Syariyah dengan biaya dari baitul mal kalau anak tersebut tidak memiliki biaya hidup dan Mahkamah Syariyah berkewajiban mengawasi pelaksanaannya.

4. Tausyiah No. 260 Tahun 2005 Tentang Renungan Tsunami dan menyambut Tahun baru 2006; berisi misalnya, kegiatan agar lebih difokuskan kepada zikir, wirid, doa, tafakkur, membaca Alquran, ceramah agama; menghindari kegiatan yang tidak

\footnotetext{
${ }^{27}$ Wawancara dengan Burhanuddin, Anggota DPRA Ketua F Bidang Pendidikan, Syariat Islam dan Ulama, Ahad 23 Mei 2009 , di Ulee Kareng, Aceh Besar.

${ }^{28}$ Dinas Syariat Islam Provinsi Aceh 2006. Himpunan Undang-Undang, Keputusan Presiden, Peraturan Daerah/Qanun, Instruksi Gubernur, Berkaitan Pelaksanaan Syariat Islam. Banda Aceh: Dinas Syariat Islam Provinsi Aceh.

${ }^{29}$ Wawancara dengan Dr. Nurjannah Ismail, Anggota Dewan Pertimbangan Ulama (DPU) MPU Provinsi Aceh, Kamis 7 Mei 2009 di Fakultas Adab IAIN Ar-Raniry, Banda Aceh.
} 
sesuai dengan run syariat seperti meniup terompet, menyalakan lilin, kembang api dan musik yang hingar bingar. ${ }^{30}$

Bahkan yang lebih luas dalam bidang ketertiban masyarakat Pemerintah Kota Banda Aceh mewajibkan bagi seseorang jika ingin membuka usaha salon atau memperpanjang izin usaha harus mencantumkan rekomendasi dari MPU, di samping rekomendasi dari kepolisian. Hal ini dilakukan agar tidak terjadi penyimpangan fungsi salon menjadi tempat prostitusi, narkoba dan minuman keras jika tidak ada rekomendasi dari MPU, maka salon tidak akan diberi izin. ${ }^{3}$

\section{Faktor-Faktor yang Memengaruhi Peran MPU}

\section{a. Keseriusan Pemerintah}

Menurut Mahfud MD bahwa hukum merupakan salah satu hasil konfigurasi politik atau lebih tepatnya produk politik. Sehingga karakter setiap produk hukum akan sangat ditentukan atau diwarnai oleh imbangan kekuatan atau konfigurasi politik yang melahirkannya. Jadi kenyataan yang muncul adalah politik yang memengaruhi produk-produk hukum, padahal seharusnya hukum yang mengatur politik. Karena itu peran politik sangat besar dalam menetapkan sebuah ketetapan hukum selama ini di Indonesia. ${ }^{32}$

Begitu juga qanun syariat Islam sebagai suatu produk politik akan sangat dipengaruhi oleh keterlibatan MPU dalam proses legislasinya. Karena MPU sebagai lembaga ulama yang terlibat dalam proses pembuatan qanun maka nuansa politis dan kepentingan kekuasaannya tidak akan ada. Sebab MPU tidak mempunyai kepentingan politik apapun dan bekerja untuk kemaslahatan umat, bahkan Muslim Ibrahim mengatakan MPU adalah legislatif independent ${ }^{3}$ Karena itu, peran pemimpin dalam hal ini keinginan politik pemerintah yang serius untuk menerapkan syariat Islam secara kaffah akan sangat menentukan. Begitu pula dengan MPU kuat dan tidaknya peran akan ditentukan oleh peran pemimpin saat ini.
Pemerintah Provinsi tidak serius dalam menjalankan syariat Islam di Aceh, sebagai contoh kasus Kepala Pengadilan Sabang yang melakukan pelanggaran Khalwat. Kasus ini tidak diproses sebagaimana mestinya. Akhirnya pelakunya menghilang dan meninggalkan Aceh sampai saat ini tidak kembali lagi. Ini merupakan salah satu bukti ketidakseriusan pemerintah, khususnya aparat hukum untuk menegakkan hukum dan melaksanakan syariat Islam. ${ }^{34}$

Sebagaimana diketahui bahwa Kepala Pengadilan Sabang pernah melakukan pelanggaran Qanun Khalwat, karena berdua-duaan dalam di sebuah tempat dengan seorang perempuan yang bukan muhrim. Perempuan tersebut bahkan mengakui bahwa ia melakukan hal tersebut Meskipun demikian pemerintah dalam hal ini pihak kepolisian dan penegak hukum yang terkait tidak melakukan tindakan, sampai saat ini kasus tersebut tidak jelas statusnya, karena Kepala Pengadilan tersebut juga telah kabur meninggalkan Aceh Sedangkan mengenai kasus tidak ditandatanganinya qanun jinayat dan hukum acara jinayat oleh Gubernur padahal sudah disetujui oleh DPRA juga menjadi kritikan masyarakat. Kedua kasus tersebut merupakan bukti ketidakseirusan pemerintah dalam melaksanakan syariat Islam di Aceh. Sebagaimana disebutkan oleh Komandan (Wilayah Hisbah) Kota Sabang;

Pemerintah belum begitu serius dalam menjalankan syariat Islam di Aceh. Hal dapat kita lihat dengan tidak ditandatanganinya qanun jinayat dan qanun acara jinayat, padahal dalam qanun tersebut diatur tentang penahanan pelaku pelanggar qanun syariat Islam. Pasal penahanan tersebut sangat dibutuhkan WH dalam proses kerja di lapangan. Memang yang bermasalah adalah pasal tentang rajam, tapi mengapa pasal tersebut tidak dikeluarkan saja, dan pasal yang lain disahkan. Jangan mengorbankan pasal lain, karena hanya satu pasal saja. ${ }^{35}$

Terkait dengan relasi antara keseriusan pemerintah dengan peran MPU juga dapat dilihat dari kasus 14 aliran sesat yang dilarang menyebarkan ajarannya pada April 2011. ${ }^{36}$ Saat itu gubernur tidak melibatkan MPU dalam pengumuman aliran dan lembaga yang

${ }^{30}$ Kumpulan Keputusan Majelis Permusyawaratan Ulama Provinsi Aceh, Banda Aceh: Sekretariat MPU Provinsi Aceh Tahun Anggaran 2008, terutama h. 80, 83, 114, dan 137.

Serambi Indonesia, [Pemkot Perketat Izin Buka Salon], Edisi, 24 Nopember 2011.

${ }^{32}$ M. Mahfud MD 1999. Pergulatan Politik dan Hukum di Indonesia, Yogyakarta: Gama Media, h. 4-27.

${ }^{33}$ Muslim Ibrahim, Rekonstruksi Peran Ulama..., h. 245-252.

is Wawancara dengan Drs. Tgk. Usman Noris, anggota MPU Kota Sabang, Selasa, 25 Oktober 2011, di Kota Sabang.

${ }^{35}$ Wawancara dengan Teungku Adi Zulfikar, Komandan WH, Selasa 25 Oktober 2011, di Kantor WH Sabang, Kota Sabang.

${ }^{3}$ Serambi Indonesia, [Pemerintah Aceh Melarang 14 Aliran Keagamaan], Edisi, 7 April 2011. 
terkait dengan aliran sesat, padahal yang mempunyai kapasitas dan otoritas untuk mengatakan sesat atau tidak adalah lembaga MPU, bukan gubernur. Meskipun dalam pemberitaan media bahwa dalam penentuan 14 aliran sesat tersebut melibatkan MPU, namun demikian dibantah kembali oleh Ketua MPU, Muslim Ibrahim. ${ }^{37}$

Ketika pemerintah tidak mempunyai keseriusan dalam menjalankan syariat Islam, maka yang jelas akan mempengaruhi peran MPU. Sebab pemerintah merupakan lembaga yang bertanggung jawab secara yuridis dalam pelaksanaan syariat Islam. Pemerintah yang bertanggung jawab mensosialisasikan, mengawasi dan mengevaluasi jalan qanun melalui Dinas syariat Islam, Kepolisian, Mahkamah Syariyah dan WH. Sedangkan MPU hanya berada pada tataran pengawas, pengingat dan pemberi tausiyah, tidak berada langsung di lapangan.

Sebagai perbandingan keseriusan pemerintah dalam mengaplikasikan syariat Islam, di Kabupaten Aceh Barat, melalui Bupati Ramli MS, mengeluarkan Peraturan Bupati (Perbup) tentang jilbab dan pakaian muslimah. Perbup ini dikeluarkan oleh bupati agar perempuan memakai jilbab dan tidak memakai pakaian ketattermasuk celana jeans. Bupati menyediakan ratusan rok yang dibagikan kepada perempuan yang memakai celana jeans dan ketat pada saat razia yang dilakukan oleh WH. Sebelum peraturan tersebut dikeluarkan, Bupati Ramli MS banyak berkonsultasi dengan ulama dan MPU yang ada di Aceh Barat, pihak MPU dan ulama mendukung ide tersebut. Terlepas dari efektif dan tidaknya Perbup tersebut, tetapi yang jelas Ramli MS telah melakukan sebuah keberanian dan terobosan untuk menciptakan sebuah cita-cita agar perempuan memakai pakaian yang sopan bagi muslimah. Hal ini tidak terlihat pada level gubernur dan bupati atau walikota lainnya di Aceh. Terkait dengan penerapan syariat Islam diperlukan keseriusan dan keberanian pemimpin agar harapan masyarakat dapat berjalan dengan baik.

\section{b. SDM MPU}

Sumber daya manusia dalam lembaga MPU juga akan berpengaruh pada perannya dalam pelaksanaan syariat Islam di Aceh. Sebagai contoh dalam proses legislasi qanun, seorang ulama yang ada dalam MPU harus menguasai atau paling tidak mengetahui hukum formal yang ada di Indonesia. Sebab qanun syariat
Islam di Aceh sebelum dibahas dan diundangkan oleh DPRA dan pemerintah, pihak MPU dapat membuat draft, kemudian diajukan ke DPRA selanjutnya dibahas. Pada konteks ini, seorang anggota harus menguasai ilmu tidak hanya ilmu-ilmu keislaman, seperti fiqih, ushul flqih, tafsir, hadis tetapi juga hukum umum, sistem hukum, hierarki hukum, legal drafting, perundangan-undangan. Sebagaimana diakui oleh ketua MPU Provinsi Aceh:

Faktor yang mempengaruhi MPU dalam proses legislasi qanun adalah anggota MPU sendiri yang tidak semuanya menguasai hukum formal sebagaimana yang diterapkan di Indonesia. Seperti legal drafting, hierarki hukum dan sebagainya. Untuk menutupi hal tersebut dalam MPU ada bidang yang bertugas membuat rancangan qanun yaitu Bidang Hukum dan PerundangUndangan. Proses pembahasan sebuah rancangan qanun turut diundang pakar dan ahli di bidang Hukum formal dan syariat Islam, Unsyiah dan IAIN. ${ }^{38}$

Ulama yang tergabung dalam keanggotaan MPU lebih banyak memiliki latar belakang Dayah dan intelektual IAIN, maka untuk menutupi kekurangan tersebut dapat diatasi dengan mengundang pakar hukum dari Unsyiah yang menguasai hukum umum. Para ulama saat ini (bukan hanya di Aceh) menyadari bahwa untuk menjawab persoalan-persoalan kontemporer pelibatan pakar ilmu-ilmu umum merupakan sesuatu yang harus dilakukan. Misalnya dalam menentukan kehalalan sebuah makanan, minuman atau obat, maka tentu harus mengundang pakar di bidangnya masing-masing untuk menemukan sebuah konklusi hukum yang jelas. Begitu juga MPU di Aceh telah mengundang dan nielibatkan pakar hukum dalam proses legislasi qanun syariat Islam.

Selain penguasaan ilmu hukum umum, peran MPUjuga dipengaruhi oleh faktor profesionalisme, etos kerja, dan energisitas. Sebagaimana dikemukakan oleh Nurjannah Ismail;

Faktor yang mempengaruhi peran MPU dalam adalah profesionalisme, keilmuan, etos kerja dan energisitas. Faktor komunikasi dengan pemerintah juga berpengaruh. Karena jika lembaga ini betul-betul berdaya dan bekerja secara profesional maka MPU ke depan akan semakin baik. ${ }^{39}$

\footnotetext{
37 Serambi Indonesia, [MPU Tidak Infokan Aliran Sesat], Edisi, 13 April 2011.

${ }^{3 *}$ Wawancara dengan Prof. Dr. Muslim Ibrahim, Ketua MPU Provinsi Aceh dan Guru Besar IAIN Ar-Raniry, Rabu 29 April 2009 di Kantor MPU, Banda Aceh

${ }^{39}$ Wawancara dengan Burhanuddin, Anggota DPRA Ketua F Bidang Pendidikan, Syariat Islam dan Ulama, Ahad 23 Mei 2009 , di Ulee Kareng, Aceh Besar.
} 


\section{c. Legitimasi Masyarakat}

Legitimasi masyarakat yang dimaksud disini adalah kepercayaan dan harapan masyarakat kepada MPU sebagai lembaga ulama yang mempunyai akar yang kuat. Peran sentral ulama dalam masyarakat terus dimainkan secara terus menerus menjadikannya sebagai salah satu kelompok elit sebagaimana sultan. Karakter masyarakat Aceh yang kental dengan nilainilai Islam juga turut mendukung dengan menjadikan ulama sebagai panutan sebagaimana Nabi dan Rasul. Masyarakat Aceh meyakini bahwa ulama adalah pewaris para Nabi dan Rasul. Hal ini diakui oleh Misri A. Muhsin.

Ulama memiliki legitimasi secara sosiokultural dan sosiopolitik dalam masyarakat Aceh disebabkan karena sejak zaman kesultanan, ulama telah menjadi mitra pemerintah dalam menjalankanroda pemerintahan. Saat itu ulama merupakan kelompok elit sosial dan elit masyarakat yang dapat dikatakan sebagai pemimpin masyarakat pada level agama. Pandangan dan katakata ulama dituruti, ditaati, karena masyarakat meyakini bahwa ulama merupakan pewaris para Nabi dan Rasul, karena itu ketaatan pada ulama merupakan manifestasi dari ketaatan pada Rasul. Dalam menjalankan tugasnya sebagai mitra pemerintah, ulama memberikan fatwa tentang persoalan hukum dan hal-hal yang berkenaan dengan masyarakat. Pada konteks ini yang menjadikan ulama mempunyai legitimasi secara historis dan sosiologis dalam strata serta stratifikasi sosial. ${ }^{40}$

Selain itu, sebuah penelitian dilakukan oleh Pusat Kajian Pendidikan dan Masyarakat (PKPM) pada 6 kabupaten di seluruh Aceh yang salah satu pertanyaan penelitiannya mengidentifikasi posisi ulama dalam penentuan kebijakan daerah. Hasilnya 44,8\% menjawab sangat setuju, 38,0\% menjawab setuju, 8,9\% menjawab kurang setuju, 7,6\% menjawab tidak setuju dan yang menjawab sangat tidak setuju hanya $3,8 \%{ }^{41}$ Bukti lain yang menunjukkan kuatnya pengaruh MPU dalam masyarakat adalah pembatalan konser kelompok band Nidji (salah satu grup band papan atas Indonesia) di Banda Aceh. Konser yang sedianya akan digelar hari Sabtu dan Minggu (25 dan 26 Agustus 2007) di Komplek Taman Ratu Syafiatudin Banda Aceh terpaksa dibatalkan karena tidak mendapat izin dari
MPU. Pihak MPU khawatir penonton akan berbuat mesum karena akan bercampur laki-laki dan perempuan serta melanggar qanun syiar Islam. ${ }^{42}$

Hal ini membuktikan bahwa MPU masih mempunyai legitimasi yang kuat dalam masyarakat dalam artian bahwa apa yang fatwakan dan disuarakan oleh MPU didengar dan dipatuhi oleh masyakarat. Sehingga dengan demikian hubungan antara legitimasi masyarakat dengan peran MPU dalam peneraparan syariat Islam cukup kuat, karena semakin tinggi legitimasi masyarakat maka peran MPU akan semakin tampak dan nyata. Sebaliknya, jika legitimasi masyarakat menurun atau tidak ada sama sekali, maka yakin dan percaya peran MPU akan turut melemah. Sebab jika dibandingkan antara DPRA dan MPU, DPRA terpilih dengan pemilihan secara langsung dan mendapat mandat dengan suara terbanyak dari masyarakat, sedangkan anggota MPU mandatnya tidak secara langsung, tetapi disebabkan karena ilmu, kharisma dan akhlak dari ulama itu sendiri sehingga seseorang dianggap sebagai ulama. Karena itu disinilah letak pentingnya legitimasi masyarakat dan menjadi sebuah keniscayaan.

\section{PENUTUP}

\section{Kesimpulan}

MPU sebagai lembaga ulama yang memiliki legitimasi historis, yuridis, dan kultural memainkan peran yang cukup sentral dalam pelaksanaan syariat Islam di Aceh. Peran yang dimainkan yaitu: memberikan pertimbangan terhadap kebijakan daerah, meliputi bidang pemerintahan, pembangunan, ekonomi, sosial budaya, dan kemasyarakatan. Kemudian memberikan nasehat dan bimbingan kepada masyarakat berdasarkan ajaran Islam. Selanjutnya melakukan penelitian, pengembangan, penerjemahan, penerbitan, dan pendokumentasian terhadap naskah-naskah yang berkenaan dengan syariat Islam, serta melakukan pengkaderan ulama.

Pada konteks ini MPU kembali mereposisi diri menjadi lembaga yang mempunyai otoritas dan kewenangan dalam hal kebijakan daerah dan pemerintahan. Hal ini menunjukkan bahwa MPU mempunyai nilai tawar dengan pihak eksekutif dan legislatif

\footnotetext{
${ }^{40}$ Wawancara dengan Prof. Misri A. Muhsin, Guru Besar Sejarah IAIN Ar-Raniry dan Dekan Fakultas Adab, Kamis 30 April 2009 di IAIN Ar-Raniry, Banda Aceh.

${ }^{4}$ Muslim Zainuddin (et.al) 2006. Posisi dan Peran Ulama di Provinsi Nanggroe Aceh Darussalam, Banda Aceh: PKPM bekerjasama dengan SATKER Agama BRR, h. 43-44.

${ }^{42}$ www.okezone.com. diakses, 24 September 2009.
} 
serta seluruh stakeholder di Aceh. Hal ini menunjukkan bahwa di Aceh terjadi proses reposisi lembaga ulama melalui MPU dibanding dengan provinsi atau daerah lain di Indonesia. Kemudian hal-hal yang dapat memengaruhi peran MPU adalah keseriusan pemerintah yang masih rendah, SDM MPU sudah memadai, meskipun masih perlu ditingkatkan dan legitimasi masyarakat yang cukup tinggi.

\section{Rekomendasi}

Penelitian ini menurut penulis belum maksimal karena lembaga ulama yang ada di Aceh bukan hanya MPU, tetapi juga ada lembaga lainnya, misalnya Himpunan Ulama Day ah (HUD A) dan Majelis Ulama Nanggroe Aceh (MUNA). HUDA merupakan lembaga ulama yang terdiri dari kalangan Dayah (pesantren) Salafiyah yang ada di Aceh, sedangkan MUNA adalah lembaga ulama yang muncul pada MoU Helsinki yang didominasi dari kalangan mantan Gerakan Aceh Merdeka (GAM) dan dekat dengan Partai Aceh sebagai pemenang pemilu 2009. Kedua lembaga ini tentunya mempunyai basis massa tersendiri dan hal ini dapat memengaruhi peran lembaga ulama satu sama lainnya dalam pelaksanaan syariat Islam maupun dalam bidang lain. Kajian terhadap kedua lembaga akan menjadi menarik jika dilihat dari peran dan pengaruhnya dalam masyarakat dan pemerintah di Aceh.

\section{Ucapan Terima Kasih}

Penelitian ini tidak akan dapat dirampungkan sebagaimana yang diharapkan jika tidak ada bantuan dan dukungan dari berbagai pihak. Karena itu penulis menyampaikan penghargaan dan ucapan terimah kasih yang setinggi-tingginya kepada sejumlah pihak. Pertama, Aceh Research Training Institute (ARTI) dan seluruh jajarannya terutama kepada Prof. Michel Leigh (Australia), Dr. Laura Yoder (USA) dan Prof. Dr. Harold Crouch (Australia), yang menfasilitasi dan memberikan bantuan teori dan materi kepada penulis dan beberapa orang peneliti lainnya selama training (level I-III) dan studi lapangan selama 6 bulan; kedua, pembimbing penelitian Steven Drakeley, PhD (University of Western Sydney, Australia), Dr. Arskal Salim (Aga Khan University, London) dan Prof. Dr. Rusdji Ali Muhammad (IAIN Ar-Raniry, Banda Aceh) yang telah memberikan arahan dan bimbingan selama penelitian berlangsung; ketiga, Rektor Universitas Malikussaleh, Prof. Hadi Arifin (mantan rektor) dan Apridar, M.Si (rektor saat ini), serta Dekan FISIPOL Unimal, Fauzi, S.Sos, MA yang memberikan bantuan dan dukungan; keempat, seluruh narasumber yang telah memberikan keterangan pada saat wawancara Terakhir kepada Dewan Redaktur Jurnal Al Qalam Balai Penelitian dan Pengambangan Agama Makassar yang berkenan menerbitkan hasil penelitian ini, serta seluruh pihak yang tidak dapat disebutkan satu persatu.

\section{DAFTAR PUSTAKA}

Abubakar, Al Yasa, dkk 2004., Penerapan Syari 'at Islam di Indonesia: Antara Peluang dan Tantangan, Jakarta: Globalmedia.

Abubakar, Al Yasa' 2005. Syari'at Islam di Provinsi Aceh Paradigma Kebijakan dan Kegiatan, Banda Aceh: Dinas Syari'at Islam prov. Nanggroe Aceh Darussalam.

Adan, Hasanuddin Yusuf 2007. Teungku Muhammad Daud Beureueh dan Perjuangan Pemberontakan diAceh, Banda Aceh: Ar-Raniry Press.

Amal, Taufik Adnan dan Syamsu Rizal Panggabean 2004. Politik Syariat Islam: Dari Indonesia Hingga Nigeria, Jakarta: Pustaka Alvabet.

Azra, Azyumardi 1998. Jaringan Ulama: Timur-Tengah dan Kepulauan Nusantara Abad XVII dan XVIII Melacak AkarAkar Pembaharuan Pemikiran Islam di Indonesia, Jakarta: Kencana.

Djuned, Daniel 2002. Syariat Bagaimana Yang Mesti Diaplikasikan? Dalam Fairus M. Nur Ibr, Syari 'at di Wilayah Syariat: Pernik-Pemik Islam di Nanggroe Aceh Darussalam, Banda Aceh: Dinas Syari'at Islam.

Dinas Syariat Islam Provinsi Aceh 2006. Himpunan UndangUndang, Keputusan Presiden, Peraturan Daerah/Qanun, Instruksi Gubernur, Berkaitan Pelaksanaan Syariat Islam, Banda Aceh: Dinas Syariat Islam Provinsi Aceh.

Ibrahim, Muslim 2002. Rekonstruksi Peran Ulama di Masa Depan, dalam Dalam Fairus M. Nur Ibr, Syari 'atdi Wilayah Syariat: Pernik-Pernik Islam di Nanggroe Aceh Darussalam, Banda Aceh: Dinas Syari'at Islam.

Ka'bah, Rifyal 2004. Penegakan Syari'at Islam di Indonesia, Jakarta: Khairul Bayan.

Kumpulan Keputusan Majelis Permusyawaratan Ulama Provinsi Aceh 2008. Banda Aceh: Sekretariat MPU Provinsi Aceh Tahun Anggaran.

Mahfud MD, M. 1999. Pergulatan Politik dan Hukum di Indonesia, Yogyakarta: Gama Media.

Moleong, Lexi J 1997 Metodologi Penelitian Kualitatif, (Bandung: Rosda Karya.

Mu'min, Ma'mun 1998. Peran Dakwah dan Politik Ulama Kekaryaan di Daerah Istimewa Aceh, (Banda Aceh: Program Pascasarjana IAIN Ar-Raniry

Muhammad, Rusjdi Ali 2003. Revitalisasi Syari 'atIslam diAceh: Problem, Solusi dan Implementasi Menuju Pelaksanaan Hukum Islam di Nanggroe Aceh Darussalam, (Jakarta: Logos Wacana IImu.

Perda Nomor 3 Tahun 2000 Tentang Pembentukan Organisasi dan Tata Kerja Majelis Permusyawaratan Ulama (MPU) Provinsi Daerah Istimewa Aceh. 
serta seluruh stakeholder di Aceh. Hal ini menunjukkan bahwa di Aceh terjadi proses reposisi lembaga ulama melalui MPU dibanding dengan provinsi atau daerah lain di Indonesia. Kemudian hal-hal yang dapat memengaruhi peran MPU adalah keseriusan pemerintah yang masih rendah, SDM MPU sudah memadai, meskipun masih perlu ditingkatkan dan legitimasi masyarakat yang cukup tinggi.

\section{Rekomendasi}

Penelitian ini menurut penulis belum maksimal karena lembaga ulama yang ada di Aceh bukan hanya MPU, tetapi juga ada lembaga lainnya, misalnya Himpunan Ulama Dayah (HUD A) dan Majelis Ulama Nanggroe Aceh (MUNA). HUDA merupakan lembaga ulama yang terdiri dari kalangan Dayah (pesantren) Salafiyah yang ada di Aceh, sedangkan MUNA adalah lembaga ulama yang muncul pada MoU Helsinki yang didominasi dari kalangan mantan Gerakan Aceh Merdeka (GAM) dan dekat dengan Partai Aceh sebagai pemenang pemilu 2009. Kedua lembaga ini tentunya mempunyai basis massa tersendiri dan hal ini dapat memengaruhi peran lembaga ulama satu sama lainnya dalam pelaksanaan syariat Islam maupun dalam bidang lain. Kajian terhadap kedua lembaga akan menjadi menarik jika dilihat dari peran dan pengaruhnya dalam masyarakat dan pemerintah di Aceh.

\section{Ucapan Terima Kasih}

Penelitian ini tidak akan dapat dirampungkan sebagaimana yang diharapkan jika tidak ada bantuan dan dukungan dari berbagai pihak. Karena itu penulis menyampaikan penghargaan dan ucapan terimah kasih yang setinggi-tingginya kepada sejumlah pihak. Pertama, Aceh Research Training Institute (ART I) dan seluruh $\mathrm{j}$ ajar army a terutama kepada Prof. Michel Leigh (Australia), Dr. Laura Yoder (USA) dan Prof. Dr. Harold Crouch (Australia), yang menfasilitasi dan memberikan bantuan teori dan materi kepada penulis dan beberapa orang peneliti lainnya selama training (level I-III) dan studi lapangan selama 6 bulan; kedua, pembimbing penelitian Steven Drakeley, PhD (University of Western Sydney, Australia), Dr. Arskal Salim (Aga Khan University, London) dan Prof. Dr. Rusdji Ali Muhammad (IAIN Ar-Raniry, Banda Aceh) yang telah memberikan arahan dan bimbingan selama penelitian berlangsung; ketiga, Rektor Universitas Malikussaleh, Prof. Hadi Arifin (mantan rektor) dan Apridar, M.Si (rektor saat ini), serta Dekan FISIPOL Unimal, Fauzi, S.Sos, MA yang memberikan bantuan dan dukungan; keempat, seluruh narasumber yang telah memberikan keterangan pada saat wawancara Terakhir kepada Dewan Redaktur Jurnal Al Qalam Balai Penelitian dan Pengambangan Agama Makassar yang berkenan menerbitkan hasil penelitian ini, serta seluruh pihak yang tidak dapat disebutkan satu per satu.

\section{DAFTAR PUSTAKA}

Abubakar, Al Yasa, dkk 2004., Penerapan Syari 'at Islam di Indonesia: Antara Peluang dan Tantangan, Jakarta: Globalmedia.

Abubakar, Al Yasa' 2005. Syari'at Islam di Provinsi Aceh Paradigma Kebijakan dan Kegiatan, Banda Aceh: Dinas Syari'at Islam prov. Nanggroe Aceh Darussalam.

Adan, Hasanuddin Yusuf 2007. Teungku Muhammad Daud Beureueh dan Perjuangan Pemberontakan di Aceh, Banda Aceh: Ar-Raniry Press.

Amal, Taufik Adnan dan Syamsu Rizal Panggabean 2004. Politik Syariat Islam: Dari Indonesia Hingga Nigeria, Jakarta: Pustaka Alvabet.

Azra, Azyumardi 1998. Jaringan Ulama: Timur-Tengah dan Kepulauan Nusantara Abad XVIIdan XVIII Melacak AkarAkar Pembaharuan Pemikiran Islam di Indonesia, Jakarta: Kencana.

Djuned, Daniel 2002. Syariat Bagaimana Yang Mesti Diaplikasikan? Dalam Fairus M. Nur Ibr, Syari'at di Wilayah Syariat: Pernik-PernikIslam di Nanggroe Aceh Darussalam, Banda Aceh: Dinas Syari'at Islam.

Dinas Syariat Islam Provinsi Aceh 2006. Himpunan UndangUndang, Keputusan Presiden, Peraturan Daerah/Qamm, Instruksi Gubernur, Berkaitan Pelaksanaan Syariat Islam, Banda Aceh: Dinas Syariat Islam Provinsi Aceh.

Ibrahim, Muslim 2002. Rekonstruksi Peran Ulama di Masa Depan, dalam Dalam Fairus M. Nur Ibr, Syari 'atdi Wilayah Syariat: Pernik-Pernik Islam di Nanggroe Aceh Darussalam, Banda Aceh: Dinas Syari'at Islam.

Ka'bah, Rifyal 2004. Penegakan Syari'at Islam di Indonesia, Jakarta: Khairul Bayan.

Kumpulan Keputusan Majelis Permusyawaratan Ulama Provinsi Aceh 2008. Banda Aceh: Sekretariat MPU Provinsi Aceh Tahun Anggaran.

Mahfud MD, M. 1999. Pergulatan Politik dan Hukum di Indonesia, Yogyakarta: Gama Media.

Moleong, Lexi J 1997. Metodologi Penelitian Kualitatif, (Bandung. Rosda Karya.

Mu'min, Ma'mun 1998. Peran Dakwah dan Politik Ulama Kekaryaan di Daerah Istimewa Aceh, (Banda Aceh: Program Pascasarjana IAIN Ar-Raniry.

Muhammad, Rusjdi Ali 2003. Revitaiisasi Syari 'at Islam di Aceh : Problem, Solusi dan Implementasi Menuju Pelaksanaan Hukum Islam di Nanggroe Aceh Darussalam, (Jakarta: Logos Wacana Ilmu.

Perda Nomor 3 Tahun 2000 Tentang Pembentukan Organisasi dan Tata Kerja Majelis Permusyawaratan Ulama (MPU) Provinsi Daerah Istimewa Aceh. 


\section{c. Legitimasi Masyarakat}

Legitimasi masyarakat yang dimaksud disini adalah kepercayaan dan harapan masyarakat kepada MPU sebagai lembaga ulama yang mempunyai akar yang kuat. Peran sentral ulama dalam masyarakat terus dimainkan secara terus menerus menjadikannya sebagai salah satu kelompok elit sebagaimana sultan. Karakter masyarakat Aceh yang kental dengan nilainilai Islam juga turut mendukung dengan menjadikan ulama sebagai panutan sebagaimana Nabi dan Rasul. Masyarakat Aceh meyakini bahwa ulama adalah pewaris para Nabi dan Rasul. Hal ini diakui oleh Misri A. Muhsin.

Ulama memiliki legitimasi secara sosiokultural dan sosiopolitik dalam masyarakat Aceh disebabkan karena sejak zaman kesultanan, ulama telah menjadi mitra pemerintah dalam menjalankanroda pemerintahan. Saat itu ulama merupakan kelompok elit sosial dan elit masyarakat yang dapat dikatakan sebagai pemimpin masyarakat pada level agama. Pandangan dan katakata ulama dituruti, ditaati, karena masyarakat meyakini bahwa ulama merupakan pewaris para Nabi dan Rasul, karena itu ketaatan pada ulama merupakan manifestasi dari ketaatan pada Rasul. Dalam menjalankan tugasnya sebagai mitra pemerintah, ulama memberikan fatwa tentang persoalan hukum dan hal-hal yang berkenaan dengan masyarakat. Pada konteks ini yang menjadikan ulama mempunyai legitimasi secara historis dan sosiologis dalam strata serta stratifikasi sosial. ${ }^{40}$

Selain itu, sebuah penelitian dilakukan oleh Pusat Kajian Pendidikan dan Masyarakat (PKPM) pada 6 kabupaten di seluruh Aceh yang salah satu pertanyaan penelitiannya mengidentifikasi posisi ulama dalam penentuan kebijakan daerah. Hasilnya 44,8\% menjawab sangat setuju, 38,0\% menjawab setuju, $8,9 \%$ menjawab kurang setuju, 7,6\% menjawab tidak setuju dan yang menjawab sangat tidak setuju hanya $3,8 \%{ }^{41}$ Bukti lain yang menunjukkan kuatnya pengaruh MPU dalam masyarakat adalah pembatalan konser kelompok band Nidji (salah satu grup band papan atas Indonesia) di Banda Aceh. Konser yang sedianya akan digelar hari Sabtu dan Minggu (25 dan 26 Agustus 2007) di Komplek Taman Ratu Syafiatudin Banda Aceh terpaksa dibatalkan karena tidak mendapat izin dari
MPU. Pihak MPU khawatir penonton akan berbuat mesum karena akan bercampur laki-laki dan perempuan serta melanggar qanun syiar Islam. ${ }^{42}$

Hal ini membuktikan bahwa MPU masih mempunyai legitimasi yang kuat dalam masyarakat dalam artian bahwa apa yang fatwakan dan disuarakan oleh MPU didengar dan dipatuhi oleh masyakarat. Sehingga dengan demikian hubungan antara legitimasi masyarakat dengan peran MPU dalam peneraparan syariat Islam cukup kuat, karena semakin tinggi legitimasi masyarakat maka peran MPU akan semakin tampak dan nyata. Sebaliknya, jika legitimasi masyarakat menurun atau tidak ada sama sekali, maka yakin dan percaya peran MPU akan turut melemah. Sebab jika dibandingkan antara DPRA dan MPU, DPRA terpilih dengan pemilihan secara langsung dan mendapat mandat dengan suara terbanyak dari masyarakat, sedangkan anggota MPU mandatnya tidak secara langsung, tetapi disebabkan karena ilmu, kharisma dan akhlak dari ulama itu sendiri sehingga seseorang dianggap sebagai ulama. Karena itu disinilah letak pentingnya legitimasi masyarakat dan menjadi sebuah keniscayaan.

\section{PENUTUP}

\section{Kesimpulan}

MPU sebagai lembaga ulama yang memiliki legitimasi historis, yuridis, dan kultural memainkan peran yang cukup sentral dalam pelaksanaan syariat Islam di Aceh. Peran yang dimainkan yaitu: memberikan pertimbangan terhadap kebijakan daerah, meliputi bidang pemerintahan, pembangunan, ekonomi, sosial budaya, dan kemasyarakatan. Kemudian memberikan nasehat dan bimbingan kepada masyarakat berdasarkan ajaran Islam. Selanjutnya melakukan penelitian, pengembangan, penerjemahan, penerbitan, dan pendokumentasian terhadap naskah-naskah yang berkenaan dengan syariat Islam, serta melakukan pengkaderan ulama.

Pada konteks ini MPU kembali mereposisi diri menjadi lembaga yang mempunyai otoritas dan kewenangan dalam hal kebijakan daerah dan pemerintahan. Hal ini menunjukkan bahwa MPU mempunyai nilai tawar dengan pihak eksekutif dan legislatif

\footnotetext{
"Wawancara dengan Prof. Misri A. Muhsin, Guru Besar Sejarah IAIN Ar-Raniry dan Dekan Fakultas Adab, Kamis 30 April 2009 di IAIN Ar-Raniry, Banda Aceh.

"Muslim Zainuddin (et.al) 2006. Posisi dan Peran Ulama di Provinsi Nanggroe Aceh Darussalam, Banda Aceh: PKPM bekerjasama dengan SATKER Agama BRR, h. 43-44.

${ }^{42}$ www.oke20ne.com. diakses, 24 September 2009.
} 
serta seluruh stakeholder di Aceh. Hal ini menunjukkan bahwa di Aceh terjadi proses reposisi lembaga ulama melalui MPU dibanding dengan provinsi atau daerah lain di Indonesia. Kemudian hal-hal yang dapat memengaruhi peran MPU adalah keseriusan pemerintah yang masih rendah, SDM MPU sudah memadai, meskipun masih perlu ditingkatkan dan legitimasi masyarakat yang cukup tinggi.

\section{Rekomendasi}

Penelitian ini menurut penulis belum maksimal karena lembaga ulama yang ada di Aceh bukan hanya MPU, tetapi juga ada lembaga lainnya, misalnya Himpunan Ulama Dayah (HUDA) dan Majelis Ulama Nanggroe Aceh (MUNA). HUDA merupakan lembaga ulama yang terdiri dari kalangan Dayah (pesantren) Salafiyah yang ada di Aceh, sedangkan MUNA adalah lembaga ulama yang muncul pada MoU Helsinki yang didominasi dari kalangan mantan Gerakan Aceh Merdeka (GAM) dan dekat dengan Partai Aceh sebagai pemenang pemilu 2009. Kedua lembaga ini tentunya mempunyai basis massatersendiri dan hal ini dapat memengaruhi peran lembaga ulama satu sama lainnya dalam pelaksanaan syariat Islam maupun dalam bidang lain. Kajian terhadap kedua lembaga akan menjadi menarik jika dilihat dari peran dan pengaruhnya dalam masyarakat dan pemerintah di Aceh.

\section{Ucapan Terima Kasih}

Penelitian ini tidak akan dapat dirampungkan sebagaimana yang diharapkan jika tidak ada bantuan dan dukungan dari berbagai pihak. Karena itu penulis menyampaikan penghargaan dan ucapan terimah kasih yang setinggi-tingginya kepada sejumlah pihak. Pertama, Aceh Research Training Institute (ARTI) dan seluruh jajarannya terutama kepada Prof. Michel Leigh (Australia), Dr. Laura Yoder (USA) dan Prof. Dr. Harold Crouch (Australia), yang menfasilitasi dan memberikan bantuan teori dan materi kepada penulis dan beberapa orang peneliti lainnya selama training (level I-III) dan studi lapangan selama 6 bulan; kedua, pembimbing penelitian Steven Drakeley, PhD (University of Western Sydney, Australia), Dr. Arskal Salim (Aga Khan University, London) dan Prof. Dr. Rusdji Ali Muhammad (IAIN Ar-Raniry, Banda Aceh) yang telah memberikan arahan dan bimbingan selama penelitian berlangsung; ketiga, Rektor Universitas Malikussaleh, Prof. Hadi Arifin (mantan rektor) dan Apridar, M.Si (rektor saat ini), serta Dekan FISIPOL Unimal, Fauzi, S.Sos, MA yang memberikan bantuan dan dukungan; keempat, seluruh narasumber yang telah memberikan keterangan pada saat wawancara Terakhir kepada Dewan Redaktur Jurnal Al Qalam Balai Penelitian dan Pengambangan Agama Makassar yang berkenan menerbitkan hasil penelitian ini, serta seluruh pihak yang tidak dapat disebutkan satu per satu.

\section{DAFTAR PUSTAKA}

Abubakar, Al Yasa, dkk 2004., Penerapan Syari 'at Islam di Indonesia: Antara Peluang dan Tantangan, Jakarta: Globalmedia.

Abubakar, Al Yasa' 2005. Syari'at Islam di Provinsi Aceh Paradigma Kebijakan dan Kegiatan, Banda Aceh: Dinas Syari'at Islam prov. Nanggroe Aceh Darussalam.

Adan, Hasanuddin Yusuf 2007. Teungku Muhammad Daud Beureueh dan Perjuangan Pemberontakan diAceh, Banda Aceh: Ar-Raniry Press.

Amal, Taufik Adnan dan Syamsu Rizal Panggabean 2004. Politik Syariat Islam: Dari Indonesia Hingga Nigeria, Jakarta: Pustaka Alvabet.

Azra, Azyumardi 1998. Jaringan Ulama: Timur-Tengah dan Kepulauan Nusantara Abad XVIIdan XVIIIMe lacakAkarAkar Pembaharuan Pemikiran Islam di Indonesia, Jakarta: Kencana.

Djuned, Daniel 2002. Syariat Bagaimana Yang Mesti Diaplikasikan? Dalam Fairus M. Nur Ibr, Syari 'at di Wilayah Syariat: Pernik-Pernik Islam di Nanggroe Aceh Darussalam, Banda Aceh: Dinas Syari'at Islam.

Dinas Syariat Islam Provinsi Aceh 2006. Himpunan UndangUndang, Keputusan Presiden, Peraturan Daerah/Qanun, Instruksi Gubernur, Berkaitan Pelaksanaan Syariat Islam, Banda Aceh: Dinas Syariat Islam Provinsi Aceh.

Ibrahim, Muslim 2002. Rekonstruksi Peran Ulama di Masa Depan, dalam Dalam Fairus M. Nur Ibr, Syari 'atdi Wilayah Syariat: Pernik-Pernik Islam di Nanggroe Aceh Darussalam, Banda Aceh: Dinas Syari'at Islam.

Ka'bah, Rifyal 2004. Penegakan Syari'at Islam di Indonesia, Jakarta: Khairul Bayan.

Kumpulan Keputusan Majelis Permusyawaratan Ulama Provinsi Aceh 2008. Banda Aceh: Sekretariat MPU Provinsi Aceh Tahun Anggaran.

Mahfud MD, M. 1999. Pergulatan Politik dan Hukum di Indonesia, Yogyakarta: Gama Media.

Moleong, Lexi J 1997 Metodologi Penelitian Kualitatif, (Bandung: Rosda Karya.

Mu'min, Ma'mun 1998. Peran Dakwah dan Politik Ulama Kekaryaan di Daerah Istimewa Aceh, (Banda Aceh: Program Pascasarjana IAIN Ar-Raniry.

Muhammad, Rusjdi Ali 2003. Revitalisasi Syari'at Islam diAceh: Problem, Solusi dan Implementasi Menuju Pelaksanaan Hukum Islam di Nanggroe Aceh Darussalam, (Jakarta: Logos Wacana Ilmu.

Perda Nomor 3 Tahun 2000 Tentang Pembentukan Organisasi dan Tata Kerja Majelis Permusyawaratan Ulama (MPU) Provinsi Daerah Istimewa Aceh. 
Qanun Nomor 2 Tahun 2009 Tentang Majelis Permusyawaratan , <• Ulama.

'»aby Yusny, Islam and Social Change: The Role The Ulama In Achenese Society, (Temple University: Dissertation, 1995).

Salim, Arskal, Challenging The Seculer State: The Islamization of Law In Modern Indonesia, (Honolulu: University of Hawaii Press, 2008),

Serambi Indonesia, [MPU Tidak Infokan Aliran Sesat], Edisi, 13 April 2011.

Serambi Indonesia, [Pemerintah Aceh Melarang 14 Aliran Keagamaan], Edisi, 7 April 2011.

Serambi Indonesia, [Pemko Perketat Izin Buka Salon], Edisi, 24 Nopember 2011.

Sjamsuddin, Nazaruddin, RevolusiDi Serambi Mekah: Perjuangan Kemerdekaan dan Pertarungan Politik diAceh 1945-1949, (Jakarta: Ul-Press, 1999).

Suyanta, Sri, Peran Ulama Aceh di Reformasi, (Jakarta: Pascasarjana UTN Jakarta, 2006).

UTJRI Nomor 11 Tahun 2006 tentang Pemerintahan Aceh.

www.okezone.com, diakses, 24 September 2009.

Yeoh, Siok Cheng, Umara-Ulama-Ummah Relations and Pesantrens in Aceh Province, Indonesia: A Study of the Challenges to the Authority of a Traditionalits Kiyai, (Washington: University of Washington, 1994).

Zainuddin, Muhammad, Tarich Atjeh dan Nusantafa, (Medan: Iskandarmuda, 1961).

Zainuddin, Muslim (et.al), Posisi dan Peran Ulama di Provinsi Nanggroe Aceh Darussalam, (Banda Aceh: PKPM bekerjasama dengan SATKER Agama BRR, 2006).

Daftar Informal!

No. 18, 26, 27, 34, 35, 38, 39, 40 